\title{
Pembaharuan Hukum Acara Peradilan Agama Telaah Eksistensi Pilihan Hukum, Pasal 50 dan Pasal 86 ayat (2) UU No.7 Tahun 1989
}

\author{
Abdul Jamil
}

\section{Abstract}

Law procedure at the religious court have tremendous progress recently and it has the exact law resource because the prevailing of Acts number 7 in the years of 1989, religious judicature have a unification on law of procedure. But in their implementation the Acts number 7 in the year of 1989 has several law handicaps such as procedure case and law choice which are written on the Acts of Religious Judicature that tends to impede the existence of Religious Judicature itself. The completing for the Acts number 7 in the year of 1989 therefore deal with the common description point 2, paragraph 6 to confirm the existence of Religious Judicature which is suitable with the certainty of paragraph 2 and 49 the Acts number 1 in the year of 1989 where they are very crucial. This writing is going to discuss the problem of religious procedure law reform and the choice of law on inheritance.

\section{Pendahuluan}

Lahirnya Undang Undang No. 7 Tahun 1989 tentang Peradilan Agama' merupakan keinginan untuk memfungsikan peranan Undang Undang No.14 Tahun 1970 tentang Pokok-Pokok Kekuasaan Kehakiman. Úndang Undang Nomor 14 Tahun, 1970 mengamanatkan bahwa kekuasan tertinggi pengadilan di indonesia adalah Mahkamah Agung. Pelaksanaan kekuasan kehakiman dijalankán oleh dua peradilan yaitu: peradilan
Umum dan péradilan khusus. Ketentuan Pasal 10 ayat (1) Undang Undang No... 14 Tahùn 1970 menyatakan: "Kekuasaan kehakiman dilaksanakan oleh Pengadilan, dalam lingkungan: Peradilan Umum, Peradilan Agama, Peradilan Militer, dan peradilan Tata Usaha Negara.

Untuk merealisasi ketentuan Pasal 10 ayat (1) masing-masing peradilan mempunyai aturan dan dasar hukum sendiri-sendiri,

'Selanjutnya dalam tulisan ini UU No. 7 Tahun 1989 tentang. Peradilan Agama disebut UU Peradilan Agama. 
misalnya Peradilan Tata Usaha Negara bersadarkan Undang Undang No. 5 Tahun 1986, dan 19 tahun kemudian lahir UU Peradilañ Agama.

Apabila dicermati lebih jauh dari empat macam peradilan yang menjalankan fungsi kekuasaan kehakiman mempunyai kewajiban menerima, memeriksa, mengadili dan menyelesikan perkara bagi pencari keadilan di tingkat pertama. Fungsi ini apakah dapat dilaksanakan secara baik oleh peradilan agama? jawaban tersebut dapat dijawab ia, dapat juga dijawab tidak tergantung kasus perkasus yang itu membutuhkan pemahaman bersama antara pengadilan negeri dengan pengadilan agama, atau karena memang ketentuan pasal yang ada dalam Undangundang itu sendiri.

Peradilan agama dapat dikatakan sebagai pelaksana kekuasaan kehakiman dengan baik apabila dikaitkan dengan ketentuan Pasal 95, 98 ayat (2) dan 103. Berdasarkan ketentuan ketiga pasal itu pengadilan agama sudah dapat melaksanakan putusan dan penetapannya tanpa harus meminta terlebih dahulu fiat eksekusi dari pengadilan negeri, sebagaimana yang pernah diatur dalam Pasal 63 ayat (2) Undang-undang No. 14 Tahun 1974. Dalam kondisi tertentu pengadilan agama dapat melaksanakan putusannya secara paksa apabila para pihak yang bersengketa tidak mau melaksanakan secara sukarela dan pengadilan diminta bantuannya, bahkan sejak proses persidangan berjalan pengadilan agama sudah dapat melakukan penyitaanpenyitaan terhadap barang baik yang menjadi objek sengketa atau barang yang akan dipergunakan sebagai pemenuhan prestasi pihak yang digugat apabila nanti gugatannya dimenangkan. Peran seperti ini apabila dikaitkan dengan pendapat Abdul Rahman, maka pengadilan agama benar-benar melaksanakan fungsinya baik sebagai fungsi yuridis maupun sosiologis. ${ }^{2}$

Peran pengadilan agama menjadi dipertanyakan fungsinya apabila dikaitkan dengan ketentuan terhadap adanya masalah pilihan hukum sebagaimana diatur dalam penjelasan umum butir 2 alinea 6 , sengketa Pasal 50 dan persoalan tuntutan pihak ketiga yang diatur dalam Pasal 86 ayat (2) UU Peradilan Agama yang dalam pendapat Roihan A. Rasyid disebut sebagai ganjalan pelaksanaan kekuasaan peradilan agama. ${ }^{3}$ Persoalan tersebut apabila dikalsifikasikan, maka ada dua persoalan, yaitu; yang berkaitan dengan penjelasan umum butir 2 alinea 6 , merupakan persoalan yang bertentangan dengan Pasal 49, sedang ketentuan Pasal 50 dan persoalan tuntutan pihak ketiga yang diatur dalam Pasal 86 ayat (2) bentuk

${ }^{2}$ Abdul Rahman Umar. 1986. Keduddukan saksi dalam Peradilan Menurut Hukum Islam. Ctk. 1, Jakarta: Pustaka Al-Husna. HIm. 18. yang dimaksud pengadilan berfungsi yuridis salah satunya adalah bahwa pengadilan itu menyelesaikan perkara dengan hukum Allah, sedang yang dimaksud dengan fungsi sosiologis adalah pengadilan itu menciptakan keadilan,terjaminnya hak-hak (manusia), terpeliharanya darah,kehormatan dan harta; antara lain adalah dengan menegakkan lembaga peradilan dimana Islam telah mewajibkannya.

${ }^{3}$ Roihan A'Rásyid. 2000. Hukum Acara Peradilan Agama. Ed.2,Ctk. 7. Jakarta: Raja:Grafindo Persada. HIm. 39-44. 
nempertanyakan eksistensi peradilan agama 'Jalam memutuskan perkara tuntutan yang' terkaitan dengan hak-hak kebendaan dan emampuan menerapkan hukum acaranya di ' rengadilan agama.

Persoalan pilihan hukum dan ketentuan 'asal 50 dan 86 ayat (2) UU Peradilan Agama nerupakan masalah yang tersisa dan nengkaburkan fungsi peradilan agama sebagai pelaksana kekuasan kehakiman yang rebenarnya. Hal ini sampai sekarang menjadi tanjalan terhadap hukum acara di PengadilanIgama, meskipun untuk menghindari. sersoalan pilihan hukum telah mengeluarkan surat Edaran Mahkamah Agung No. 2 Tahun 1990 tanggal 3 April 1990 tentang Petunjuk Jelaksanaan Undang-Undang Nomor 7 Tahun 1989. SEMA ini hanya difokuskan pada jersoalan kewarisan dan inipun belum tuntas jembahasannya. SEMA ini juga belum nenyentuh pada persoalan yang menyangkut jilihan hukum dalam bidang kewarisan sebagaimana ketentuan penjelasan umúm jutir 2 alinea 6, serta ketentuan Pasal 50.

\section{Pembaharuan Hukum Acara Pengadilan} Agama

Seperti diketahui bahwa salah satu hal yang melatar belakangi lahirnya UU Peradilan Agama adalah pelaksanaan Undang Undang No. 14 Tahun 1970, untuk menggantikan dan memperbaharui peraturan perundangundangan peradilan agama yang sangat beragam: ${ }^{4}$ Tujuan ditetapkannya undangundang tersebut sebagaimana tertuang dalam konsiderannya yang. dengan tegas menyebutkan bahwa masih terdapatnya keanekaragaman pengaturan tentang susunan, kekuasaan dan hukum acara yang berlaku dalam lingkungan Peradilan Agama.

Keanekaragaman pengaturan pengadilan agama ini dapat dipahami karena sejak berdirinya secara de jure pada tahun 1882 peradilan agama yang jauh sebelum Landraad (pengadilan negeri) baik dari nama maupun dasar pengaturannya masih berbedabeda. Dari segi nama masih ada tiga náma, yaitu; Peradilan Agama di Jawa dan Madura berdasarkan Staatsblad tahun 1882 No 152, Kerapatan Qadi di Kalimantan Selatan dan sebagian Kalimatan Timur berdasarkan Staatsblad Tahun 1937 No 638 dan 639 dan Mahkamah Syari'ah di luar Jawa, Madura dan Kalimantan Selatan berdasarkan Peraturan Pemerintah No. 45 tahun 1957, dan baru mempunyai kesamaan nama yaitu "Peradilan Agama" pada tahun 1980 melalui keputusan

${ }^{4}$ Baca Achmad Roestandi dan Muchjidin Effendie S. 1991. Komentar Atas Undang-Undang No.7 Tahun 1989 Tentang Peradilan Agama Dilengkapi Kompilasi Hukum Islam. Bandung: Nusantra Press. HIm. 9.

${ }^{5}$ Mohammad Daud Ali dan Habibah Daud. 1995. Lembaga-Lembaga Islam di Indonesia. Ed. 1. Ctk.1. Jakarta: Raja Grafindo Perśada. Hlm. 113-115. dan Muhammad Daud Ali. 1997. Hukum Islam dan Peradilan Agama (Kumpulan Tulisan). Edisi 1. Ctk. 1. Jakarta: Raja Grafindo Persada. Hlim. 224-225. Baca juga M. Yahya Harahap. Kedudukan Kwenangan dan Acara Peradilan Agama Undang-Undang No. 7 Tahun 1989. Ctk. Pertama. Jakarta: Pustaka Kartini. Him.29. Menurut Yahya Harahap akibat dari perbedaan nama dan pengaturan itu juga berdampak pada kekuaan yurisdiksi peradilan agama. 
Menteri Agama tanggal 28 Januari $1980 .^{5}$

Salah satu target penyempurnaan yang dikehendaki oleh UU Peradilan Agama adalah adanya penyempurnaan dalam hukum acara yang berlaku di pengadilan agama. Sebagaimana diketahui bersama bahwa hukum acara di pengadilan agama selama ini masih bersumber pada hukum acara yang berserak-serak yang belum dikodifikasi dalam satu bentuk sumber hukum, sehingga sebelum berlakunya UU Peradilan Agama masih sangat terbuka disparitas putusan pengadilan agama karena banyaknya sumber hukum acara.

Berdasarkan ketentuan Pasal 54 undangundang tersebut, secara yuridis bahwa hukum acara yang berlaku di pengadilan agama sekarang ini ada dua sumber yang sudah terkodifikasi, yaitu hukum acara perdata yang berlaku di pengadilan umum, dan hukum acara yang secara husus diatur tersendiri dalam UU Peradilan Agama.

Untuk mekanisme beracara di pengadilan agama yang secara khusus diatur dalam undang-undang ini ada tiga hal, yaitu: (1) cerai talak, (2) cerai gugat, dan (3) cerai dengan alasan zina. Selain ketiga hal terebut tetap berlaku hukum acara perdata yang berlaku di pengadilan umum.

Pembedaan pemberlakuan ini dikarenakan ada dua hal yang prinsip, yaitu: (1) berkaitan dengan kompetensi absolut pengadilan agama. Sekarang ini kewenangan pengadilan agama tidak saja masalah cera saja, akan tetapi juga menangani perkara keperdataan tertentu, yaitu kewarisan, wasiat hibah yang didasarkan hukum Islam, waka' dan shadaqah. (2) persoalan perceraian. Persoalan perceraian di perngadilan agame didasarkan pada perkawinan yang dilakukar berdasarkan hukum perkawinan Islam, atau perkawinan yang dicatatkan di KUA, sehingga ketika melakukan perceraian, maka hukum perkawinan Islam yang dijadikan dasarnya. Oleh karena, dasar perkawinannya Islam, maka ketika seseorang itu nantinya cerai, maka hukum acara yang ada dalam hukum Islam yang akan dipergunakan untuk proses perceraiannya. Kondisi seperti ini apabila dikaitkan dengan pengertian hukum acara sangat tepat, sebab kerjanya hukum acara adalah mempertahankan hukum materiilnya. ${ }^{6}$ Hukum materiil yang diperlakukan pada saat perkawinan Islam tentu saja ketika proses perceraian harus didasarkan pada ketentuan hukum Islam.

Apabila dilihat dari hukum materiil, perceraian menurut hukum Islam ada perbedaan yang spisifik jika dibandingkan dengan hukum perdata pada umumnya. Misalnya perceraian qabla duhul (belum pernah berhubungan suami istri) maka, seorang istri wajib mengembalikan maharnya separuh kepada suaminya, oleh sebab itulah dalam praktek seseorang yang berperkara di pengadilan agama dengan pokok gugatan

${ }^{6}$ Baca Wirjono Prodjodikoro. 1980. Hukum Acara Perdata di Indonesia. Jakarta: Sumur Bandung. Hlm. 13. Bahwa yang dimaksud dengan hukum acara ialah rangkain peraturan peraturan yang memuat cara bagaimana pengadilan itu harus bertindak, satu sama lain untuk melaksanakan berjalannya peraturan hukum meteriilnya. Baca juga Sudikno Mertokususmo. 1999. Hukum Acara Perdata Indonesia. Edisi kelima. Ctk. kedua Yogyakarta: Liberty. HIm. 2. 
cerai pasti ditanya oleh hakim apakah qabla duhul atau bakda duhul.' Contoh yang lain masalah perceraian apakah yang diajukan oleh pihak suami atau yang diajukan oleh pihak istri tetap diajukan pada pengadilan agama di wilayah (domisili) seoarang istri berada; dimana proses seperti ini berbeda dengan 'ketentuan Pasal 118 HIR dengan 'syarat' apabila istri taat pada suami (tidak nusyuz) dan atau tidak berada di luar negeri, Hal ini apabila dibandingkan dengan asas kompetensi relatif di pengadilan negeri bertentengan.?

Proses beracara yang berkaitan dengán perceraian di pengadilan agama berdasarkan UU Peradilan Agama pada umumnya proses beracara lebih cenderung mengüntungkan pihak istri (perempuan). Hâl ini sängat berkaitan erat dengan prinsip hukum perkawinan dalam Islam yang merupakan lex specialis derogat lex generalis.

Pembaharuan hukum acara di pengadilan agama yang 'menyangkut permasalahan perceraian merupakan upaya pemerintah untuk melindungi hak-hak wanita dalam masalah perceraian ${ }^{8}$ atau hak seorang istri dalam perkawinan. Kenyataan yarig dalam masyarakat ada kecenderungan dalam masalah ketidak harmonisan rumah tangga apabila terjadi kasus perkawinan päda umumnya dan pérceraian khususnya posisi wanita banyak dirugikan. Sebagai contoh, banyak kejadian kalau rumah tangga dalam kondisi cekcok terus mienerus perempuan yang disuruh pergi oleh suami untuk meninggalkan 'rumah bersama' atau sebaliknya suami yang meninggalkan istrinya dan menëlantarkan istrinya, kalau istrinya tidak tahan dan dia mengajukan cerai diharuskan untuk mengajukan gugatan pada pengadilan agama yang mewilayahi domisili suami berada. Hal ini sangat merugikan pinak istri (perempuan), dan masih banyak lagi thal-hal yang berbeda proses acaranya dengan acara perdata apada umumnya.

\section{Pilihan Hukum dalam Perkara Kewarisan}

Sebagaimana telah disinggung di bagian atas bahwa pilihan hukum merupakan masalah persoâlan yang tergantung yang belum ada penyelesaian dalam UU Peradilan Agama, sebab persoalan ini bertentangan dengan Pasal 49. Ketentuan Pasal 49 merupakan "memurnikan" dan sekaligus "menyempurnakan" fungsi pengadilan agama. ${ }^{9}$ Pasal 49 mengạtur tentang kekuasan

'Bandingkan dengan asas komptensi relatifi, dalam Sudikno Mertokusumo. "Hukum Acarà...." Op. Cit. HIm: $65-67$.

${ }^{8}$ Menurut Hadari Djenawi Thaher, bahwa salah satu bentuk penyempunaan Undang-undang peradilan agama adalah melindungi kaum wanita khususnya dalam masalah perceraian, Baca "Pokok-Pokok Pikiran Dalam UU Peradilan Agama". Dalam 1989. Undang-Undang Peradilan Agama; UU RI Nomor 7 Tahun. 1989. Jakarta: Alda. Hlm: 12.

${ }^{3} \mathrm{M}$. Yahya Harahap. 1990. Kedudukan Kewenangan dan Acara Peradilan Agama Undang-Undang No.7 Tahun 1989. Ctk. Pertama. Jakarta: Pustaka Kartini. Hlm. 32. Salah satu tujuan pokok dari UU peradilan agama seperti yang diatur dalam UU No. 7 tahun 11989 bermaksud "memumikan dan sekaligus menyempumakan" fungsi dan susunan organisasi, agar dapat mencapai tingkat sebagailembaga kekuasaan kehakiman yang sebenarnya. 
pengadilan agama, yaitu; masalah perkawinan, kewarisan, wasiat, dan hibah yang dilakukan berdasarkan hukum Islam, wakaf dan shadaqah.

Pasal 49 ini apabila dikaitkan dengan Pasal 2, yang berbunyi bahwa Pengadilan agama merupakan salah satu pelaksana kekuasaan kehakiman bagi rakyat pencari keadilan yang beragama Islam mengenai perkara perdata tertentu yang diatur dalam Undang-undang ini. Dengan adanya pilihan hukum, maka batasan fungsi pengadilan agama-menjadi jelas dan kabur, sebab Pasal 49 merinci apa yang menjadi kewenangan pengadilan agama.

Apabila ditelaah ketentuan dua pasal (Pasal 2 dan 45 UU Peradilan Agama) tersebut, dapat diambil suatu pemahaman bahwa pengadilan agama pada prinsipnya hanya menangani perkara antara orang yang beragama Islam dalam hal perkawinan, kewarisan, wasiat, hibah, wakaf dan shadaqah. Dalam bahasa lain bahwa asas yang diterapkan di pengadilan agama adalah Islam, baik pada orangnya maupun perkaranya. ${ }^{10}$ Sehingga seorang yang beragama Islam sudah tidak mempunyai peluang lagi untuk tidak mau ke pengadilan agama dalam hal menyelesaikan perkara khususnya kewarisan.

Rumusan Pasal 49 memang mengandung rumusan yang mempunyai makna ganda, yaitu pada ayat (1) huruf $b$, yang kalimatnya berbunyi "kewarisan, wasiat, dan hibah, yang dilakukan berdasarkan hukum Islam". Kalimat ini dapat ditafsirkan bagaimana kalau orang Islam yang tidak mau menyelesaikan kewarisan, wasiat dan hibah berdasarkan hukum Islam, maka tentu saja tidak sesuai dengan yang dimaksud dalam jangkauan Pasal 49, sehingga meskipun dia orang yang beragama Islam kalau mempunyai masalah kewarisan tidak menjadi terikat dan menjadi kewenangan pengadilan agama. Sehingga dari makna bahasa rumusan kalimat ini menganulir kekuatan Pasal 49 itu sendiri.

Persoalan yang ada pada Pasal 49 ini juga diperkuat lagi oleh penjelasan umum butir 2 alinea 6 , yang berbunyi "sehubungan dengan hal tersebut, para pihak sebelum berperkara dapat mempertimbangkan untuk memilih hukum apa yang akan dipergunakan dalam pembagian warisan". Dalam bahasa sederhana dapat ditafsiri bahwa seseorang sebelum berperkara harus terlebih dahulu menetukan hukum mana yang akan dipergunakan sebagai alat untuk menyelesaikannya, ketentuan inilah yang kemudian dipahami sebagai wadah pilihan hukum dalam kasus waris.

Rumusan penejelasan umum butir 2 alinea 6 menyisakan dua persoalan dalam pembahasan Undang-undang peradilan agama. Persoalan itu adalah: (1) pemaknaan ganda terhadap eksistensi peradilan agama, (2) mempersulit teknis beracara bagi pencari keadilan berkaitan dengan masalah waris.

Pemaknaan ganda eksistensi pengadilan agama ini bahwa salah satu tujuan undangundang, peradilan agama adalah mengembalikan peran pengadilan agama untuk menangani perkara waris bagi orang Islam yang pernah berlaku pada abad 18-an,

${ }^{10} /$ bid. HIm. 39. 
akan tetapi, di sisi lain dalam menyelesaikan persoalan waris bagi orang Islam tidak harus ke pengadilan agama. Sehingga kalimat dalam penjelasan umum butir 2 alinea 6 menurut istilahnya Roihan A. Rasyid akan membuat kaburnya permasalahan serta àkan menimbulkan serba ketidak pastian hukum. ${ }^{11}$ Sebab orang Islami diperbolehkan tidak menggunakan ketentuan Pasal 49, meskipun sebenarnya pasal ini sebagai landasan eksistensi pengadilan agama, sebab secara eksplisit orang Islam harus ke pengadilan agama dalam perkara keperdataan tertentu sebagaimana dimaksud dalam Pasal 49. Penjelasan umum butir 2 alinea 6 Inilah kemudian dipahami sebagai landasan hak pilih (pilihan hukum) orang Islam untuk menyimpangi ketentuan Pasal 2 dan 49.

Menurut pemahaman umum yaing dimaksud pilihan hukum adalah hak untuk memilih hukum apa yang akan dipergunakan sebagai alat menyelesaikan atau untuk berbuat hukum. Apabila dikaitkan dengan pilihan hukum waris yaitu hak untuk memilih hukum apa yang akan dipergunakan untuk membagi harta warisan. ${ }^{12}$ Sebagaimana diketahui bahwa hukum waris yang berlaku di Indonesia ada tiga sistem hukum, yaitu: hukum adat, hukum Islam, dan hukum barat. Pengertian ini mempunyai suatu makna bahwa seseorang diberi kebebasan untuk memilih hukum Adat, Islam, atau hukum Barat yang dipergunakan menyelesaikan masalah waris meskipun mereka beragama Islam. Pemberian hak memilih hukum ini oleh $M$. Yahya Harahap merupakan "penganuliran" atau mementahikan ketentuan Pasal $49 .{ }^{13}$

Pemilihan hukum atau penundukan diri pada hukum mempunyai konsekuensi pada pemilihan peradilan, misälnya orang memilih (menundukkan diri) pada hukum Adat atau hukum Barat, maka bukan menjadi wewenang peradilan agama lagi, tetapi sudah menjadi wewenang pengadilan negeri, sebab' secara khusus pengadilan agama bersumber pada hukum Islam dan bukan pada hukum adat, atau hukum Barat. Itulah sebabnya penjelasan umum butir 2 alinea 6 sebagai pengebirian eksistensi dan kewenangan pengadilan agama. Dari segi kehendak ada keinginan untuk memerdekakan pengadilan agama sesuai dengan amanat Undang Undang No. 14 Tahun 1974, tetapi ada keberatan untuk melepaskan seperti layaknya pengadilanpengadilan yang lain.

Seperti yang sudah disinggung di bagian alinea sebelumnya, bahwa penjelasan umum butir 2 alinea 6 , ada konsekuensi yang berdampak selain pada eksistensi pengadilan juga menambah persoalan teknis beracara bagi pencari keadilan yang beragama Islam dalam persoalan kewarisan. Sebagaimana diketahui bahwa prinsip dasar tugas pengadilan adalah menerima, memeriksa, dan memutus perkara yang diajukan. Dalam hukum acara dalam hal pengadilan

"Roihan A Rasyid. 2000. Hukum Acara Peradilan Agama. Edisi 2. Ctk. 7. Jakarta: Raja Grafindo Persada. HIm. 41.

${ }^{12}$ lbid. HIm. 162.

${ }^{13}$ lbid. HIm. 163. 
menyelesaiakan masalah itu di bagi menjadi dua, yaitu; (1) perkara yang tidak mengandung sengketa yang disebut dengan volunter atau peradilan yang tidak sesungguhnya dan (2) contentieuse atau peradilan yang sesungguhnya. ${ }^{14}$ Pembedaan sederhana bahwa yang dimaksud peradilan volunter itu berkaitan dengan jenis perkaranya yaitu tuntutan hak yang tidak mengandung sengketa dengan orang (pihak) lain di mana hak itu diberikan oleh undang-undang dan pengajuaannya dengan istilah permohonan. Sebagai contoh kalau di pengadilan agama orang meminta izin nikah bagi seorang yang usianya kurang dari 21 tahun tetapi sudah masuk kualifikasi nikah,misalnya laki-laki sudah usia' 19 tahun, perempuan sudah 16 tahun tetapi orang tuanya tidak memberikan izin, maka orang itu dapat mengajukan permohonan ke pengadilan agama meminta penetapan izin menikah sebagai ganti izin dari orang tunya atau walinya, sedangkan peradilan yang bersifat contentieuse orang meminta bantuan pengadilan untuk menyelesaikan karena adanya hak yang dilanggar oleh pihak lain yang disebabkan adanya pengebirian undang-undang atau karena adanya hubungan hukum dan tuntutan haknya dengan mengajukan gugatan. Misalnya yang berkaitan dengan pemberian undang-undang, bahwa setiap anak itu menjadi ahli waris orang tuanya, tetapi setelah orang tuanya meninggal dunia dia tidak diberi bagian warisan oleh saudaranya dari harta warisan yang ditinggalkan oleh orang tunya.
Atau karena adanya hubungan hukum misalnya suami istri yang terikat karena perkawinan, suaminya melanggar taklikut talak misalnya tidak memberikan nafkah baik lahir maupun batin kepada istrinya, maka kalau istrinya tidak terima, maka dia harus mengajukan tuntutan haknya kepada pengadilan dengan mengajukan gugatan kepada suaminya.

Dari prinsip di atas, dapat diambil suatu pemahaman bahwa seseorang maju ke pengadilan pada prinsipnya mempunyai keinginan untuk mempertahankan hak secara tidak melawan hukum. Cara mempertahan hak yang dimaksud tentu saja adalah ketika terjadi pelanggaran hak. Kebanyakan yang terjadi di masyarakat pelanggaran hak yang berkaitan dengan kewarisan itu mengandung unsur sengketa dengan pihak lain. Berkaitan dengan itu kapan seseorang dianggap telàh memilih hukum, apakah pada saat mereka ada kompromi hukumnya ataukah pada saat dia memasukkan tuntutan haknya (gugatan)? Apabila ditelaah ketentuan penjelasan umum butir 2 alinea 6 itu, maka sebelum orang orang memasukkan gugatannya ke pengadilan. Kalau ini yang menjadi keinginan UU Peradilan Agama, maka seseorang yang mempunyai masalah kewarisan tidak perlu lagi mengajukan gugatan tuntutan hak ke pengadilan sebab sudah terjadi kompromi untuk menyelesaikan. Kasus yang ada di lapangan adalah masalah kewarisan itu tidak terjadi kesepakatan untuk menyelesaikan, bukan paḍa persoalan dasar hukumnya yang

${ }^{14}$ SudiknoMertokusumo. Op.Cit. HIm. 3-4.

${ }^{15}$ Baca M. Yahya harahap. Op. Cit. HIm. 167-170. 
digunakan untuk menyelesaikan. ${ }^{15}$

Persoalan kewarisan yang menjadi masalah di lapangan adalah berkenaan dasar penyelesaian masalah kewarisan, dari dasar inilah pemicunya persoalan kewarisan itu timbul. Misalnya ada orang tua sebut saja A mempunyai 1 (satu) anak laki-laki dan 1 (satu) anak perempuan, laki-laki mengatakan saya mendapat bagian dua kali dari anak perempuan, sedangkan yang perempuan mengatakan bagiannya sama, sehingga anak perempuannya mengatakan kakak lakilakinya telah mengambil haknya. Kasus tersebut adalah dari perbedaan dasarnya saja. Bagi anak laki-lakinya benar kalau didasarkan pada hukum Islam, anak perempuannya benar kalau didasarkan pada hukum adat. Kalau sama-sama bertahan pada dasar hukumnya, maka sama-sama benar, berarti bahwa anak perempuannya menganggap saudara lakilakinya telah merampas hak bagian kewarisannya, kalau dia tidak terima berarti dia harus menggugat kakak laki-lakinya ke pengadilan. Ke pengadilan mana dia harus menggugat? kalau didasarkan pada penafsiran penjelasan umum butir 2 alinea 6 , maka keduanya harus kompromi hukum mana yang akan dipilih, kalau hukum Islam tentu saja ke pengadilan agama, sedang kalau hukum adat ke pengadilan negeri. Dari kasus tersebut kalau sudah ada kopromi hukum mana yang dipakai menyelesaikan kasus kewarisan tersebut tentu saja tidak akan menjadi masalah bahkan sampai menggugat ke pengadilan. Kalau tidak terjadi kesepatakan hukum itulah awal mulanya terjadi sengketa kewarisan.

Untuk mencari penyelesaian terhadap persoalan pilihan hukum Mahkamah Agung pernah berupaya untuk mencari jalan keluarnya dengan membuat hukum "Penemuan dan Pemecahan Masalah Hukum dalam Peradilan Agama" tetapi belum ada penyelesaian tuntas. Sebab masih diambil suatu pemahaman pilihan hukum itu diambil pada saat mengajukan gugatan ke pengadilan, misalnya ke pengadilan agama, harus dianggap sudah memilih hukum yang akan dipergunakan dalam pembagian waris, sehingga kalau tergugat mengeksepsi, maka harus ditolak,dan begitu sebaliknya. Atau apabila tidak terjadi keduabelah pihak samasama menggugat ke dua pengadilan yang berbeda, misalnya yang satu mengajukan ke pengadilan negeri dan yang lain mengajukan ke pengadilan agama, maka diselesaikan Mahkamah Agung yang mengadili tentang sengketa kewenangan. ${ }^{16}$

Persoalan tersebut belum dapat dianggap selesai, sebab prinsip penyelesaian sengketa kewenangan itu kalau diajukan kepada Mahkamah Agung dengan cara kedua pengadilan yang berbeda kompetensi absolutnya tersebut menghentikan dan mengajukan ke Mahkamah Agung untuk meminta putusan tentang sengketa kewenangan. Apabila kedua pengadilan itu tidak menempuh prosedur tersebut berarti Mahkamah Agung tidak mengetahui dan bisa jadi nanti ada dua keputusan antara pengadilan agama dan pengadilan negeri

${ }^{16}$ Tim Proyek Peningkatan Tertib Hukum dan Pembinaan Hukum Mahkaman Agung Republik Indonesia, 1994: Penemuan dan Pemecahan Masalah Hukum Dalam Peradilan Agama. Tidak diterbitkan untuk umum. Jakarta. HIm. 78-79. 
dalam kasus yang sama dengan dasar yang berbeda. Kalau hal ini yang terjadi, maka putusan mana yang akan dilakukan eksekusi? Gambaran persoảlàn ini dapat saja terjadi entah kapan apakáh dalam waktu dekat atau yang akan datang.

\section{Pilihan Hukum dalam Hukum Acara}

Pilihan hukum dalam nuansa hukum perdata adalah hak seseorang yang diberikan secara bebas dan batasannya hanya pada tidak boleh bertentangan dengan undangundang serta norma kesusliaan. Pilihan hukum ini dilakukan untuk dasar pengaturan hukum yang akan dipergunakan sebagai landasan hukum berbuat. Sedang pilihan hukum dalam pengertian hukum acara lazim digunakan untuk menentukan domisili pengadilan apabila nanti terjadi suatu masalah hukum yang timbul di kemudian hari. Memang penentuan pengadilan akan mempunyai dampak pada dasar hukum yang akan dijadikan sebagai acuan teknis maupun yuridis dalam beracara di pengadilan tersebut. Kadang-kadang secara teknis di pengadilan yang satu berbeda dengan di pengadilan lain meskipun sama-sama satu lingkungan peradilan.

Pilihan hukum yang dimaksud dalam penjelasan umum butir 2 alinea 6 pada prinsipnya adalah memilih peradilan yang akan dipergunakan untuk menyelesaikan sengketa, dan ini tidak lazim digunakan dalam hukum acara untuk menentukan kompetensi absolut, sebab dalam hukum acara kewenangan absolut suatu pengadilan ditentukan oleh undang-undang dan bukan pada kesepakatan.

Kalau pemahaman pilihan hukum itu didasarkan pada prinsip hukum acara, maka disepakati terlebih dahulu oleh pihak-pihak yang akan bersengketa bukan ditentukan mana yang dahülu menggugat, dan ini hanya pada penentuan kompetensi relatif. Misal sebut saja A beralamat di Jakarta mengadakan perjanjian jual beli dengan $B$ yang beralamat di Surabaya keduanya telah sepakat apabila nanti ada pihak yang melakukan perbuatan wanprestasi pengadilan yang berwenang adalah dipilih Yogyakarta. Misalnya A benar wanprestasi maka B kalau dia meminta bantuan pengadilan untuk menyelesaikan masalahnya tentu dia harus mengajukan gugatan ke pengadilan negeri Yogyakarta, dan A tidak dapat menolak dengan alasan dia berada di Jakarta. Kejadian dalam contoh inilah yang sering dipakai istilah pilihan hukum dalam hukum acara.

Lain hainya juga dengan kasus yang lain, misalnya dalam kasus waris A anak laki-laki, $B$ anak perempuan keduanya beragama Islam berselisih tentang bagian waris dari orang tunya yang sudah meninggal dunia sebut $C$ yang juga beragama Islam. A menghendaki hukum Islam sesuai ketentuan agama yang diyakini, B menggunakan hukum adat, keduanya tidak ada titik temu maka $B$ menggugat $A$ ke pengadilan negeri, maka $A$ tidak dapat eksepsi dengan dalil bahwa masalah kewarisan orang Islam itu ke pengadilan agama, hal ini bukan pilihan hukum beracara tetapi cepat-cepatan menggugat. Ketentuan semacam ini sebagai mana yang sudah dibahas di bagain sebelumnya akan membingungkan pencari keadilan, karena bias jadi kasus $A$ dan $B$ itu sama sama menggugat ke pengadilan yang berbeda (ke pengadilan negeri dan pengadilan agama).

Untuk tidak membingungkan para 
pencari keadilan dan melaksanakan asas peradilan yang sederhana, cepat dan biaya murah, Mahkamah Agung sebagai pembina teknis yuridis peradilan melakukan dua cara sebagai jalan keluar, yaitu: (1) mengadakan evaluasi terhadap perkara-perkara yang menyangkut pilihan hukum itu seperti yang sudah sering dilakukan Mahkamah Agung yang dapat dijadikan masukan kepada pemerintah sebagai bahan evaluasi terhadap perlu tidaknya adanya penyempurnaan terhadap UU Peradilan Agama. (2) Memberikan pembinaan rutin kepada hakimhakim tingkat pertama untuk menempuh prosedur sengketa kewenangan untuk menghentikan sementara proses pemeriksaan untuk diajukan kepada Mahkamah Agung. Langkah ini hanya mengingatkan hakim saja, sebab kalau hakim tidak menempuh bahwa akibatnya adalah fungsi pengadilan dan tugas hakim dipertanyakan. Sebab peran hakim juga dapat mempengaruhi apakah asas peradilan sederhana, cepat, dan biaya murah itu tercapai, meskipun juga kadang-kadang para pihak juga ikut menghambat asas peradilan.

\section{Simpulan}

Hukum acara di pengadilan agama sekarang ini sudah banyak kemajuan dan mempunyai sumber hukum yang jelas, karena dengan berlakunya Undang-undang Nomor 7 tahun 1989, peradilan agama mempunyai unifikasi dalam hukum acara, yaitu hukum acara diatur secara khusus di dalam UU Peradilan Agama dan hukum acara yang berlaku di pengadilan umum yang berkaitan dengan hak-hak keperdataan dan sebagian dalam hal-hal yang menyangkut perceraian.
Dengan demikian, tidak lagi mungkin lagi menimbulkan disparitas putusan yang berbeda antara pengadilan agama yang satu dengan pengadilan agama yang lain. Perlu adanya penyempurnaan terhadap UU Peradilan Agama berkaitan dengan penjelasan umum butir 2 alinea 6 untuk mempertegas eksistensi peradilan agama sesuai dengan ketentuan Pasal 2 dan 49 UU Peradila Agama.

\section{Daftar Pustaka}

Ali, Mohammad Daud dan Habibah Daud. 1995. Lembaga-Lembaga Islam di Indonesia. Ed. 1. Ctk.1. Jakarta: Raja Grafindo Persada.

. 1997. Hukum Islam dan Peradilan Agama (Kumpulan Tulisan). Edisi 1. Ctk. 1. Jakarta: Raja Grafindo Persada.

Harahap, M. Yahya. Kedudukan Kwenangan dan Acara Peradilan Agama Undang-Undang No. 7 Tahun 1989. Ctk. Pertama. Jakarta: Pustaka Kartini. . 1990. Kedudukan Kewenangan dan Acara Peradilan Agama. UndangUndang No.7 Tahun 1989. Ctk. Pertama. Jakarta: Pustaka Kartini.

Mertokususmo, Sudikno. 1999. Hukum Acara Perdata Indonesia. Edisi kelima: Ctk. kedua Yogyakarta: Liberty.

Prodjodikoro, Wirjono. 1980. Hukum Acara Perdata di Indonesia. Jakarta: Sumur Bandung.

Rasyid; Roihan A. 2000. Hukum Acara Peradilan Agama. Edisi 2. Ctk. 7. Jakarta: Raja Grafindo Persada. 
Rasyid, Roihan A.. 2000. Hukum Acara Peradilan . Agama: Ed.2,Ctk. 7. Jakarta: Raja Grafindo Persada.

Roestandi, Achmad.dan Muchjidin Effendie

S. 1991. Komentar Atas UndangUndang No.7 Tahun 1989 Tentang Peradilan Agama Dilengkapi Kompilasi Hukum Islam. Bandung: Nusantra Press.

Thaher, Hadari Djenawi. "Pokok-Pokok Pikiran Dalam UU Peradilan Agama". Dalam 1989. Undang-Undang Peradilan
Agama; UU RI Nomor 7 Tahun 1989. Jakarta: Alda.

Tim Proyek Peningkatan Tertib Hukum dan Pembinaan Hukum Mahkaman Agung Republik Indonesia, 1994. Penemuan dan Pemecahan Masalah Hukum Dalam Peradilan Agama. Tidak diterbitkan untuk umum. Jakarta.

Umar, Abdul Rahman. 1986. Keduddukan saksi dalam Peradilan Menurut Hukum Islam. Ctk. 1, Jakarta: Pustaka Al-Husna.

๑) ค 